\title{
Cycling and public transportation sharing space: An option to increase cycling ridership
}

\author{
Patricia Cazorla \\ Master in Traffic, Logistic and Intelligent transport systems, KU Leuven, Leuven, Belgium. \\ Autor de correspondencia: nonas1998@hotmail.com
}

Fecha de recepción: 21 de abril 2017 - Fecha de aceptación: 25 de octubre 2017

\begin{abstract}
Allowing cyclists in bus lanes is an alternative to encourage diversity in mobility within consolidated cities, as this allows providing an infrastructure for cycling in places where for the limited right-of-way it is not possible to provide an independent lane. Apart of efficiency and safety, combining two modes of transport in the same space generates concerns such as the bus-cyclist interaction. Therefore, the design of shared bus-bike lanes (SBBLs) should ensure efficiency and safety for buses and cyclists. The lack of a general standard for the design of SBBLs hindered their implementation in the cities of developing countries that generally lack the human, economic and technical resources to adjust via research the design to the prevailing local conditions. This paper presents an analysis of design guidelines for SBBLs applied in Europe, North America and Australia, showing that the type of cycling infrastructure, the alignment within the SBBL and the lane width, are the parameters that should be considered to ensure safety and efficiency of these two modes. Furthermore, review of the literature on bus and bicycle mobility systems in Paris, revealed that increasing the public transport and cycling ridership not only depends on the quality of the built infrastructure, but also on the coordination between the design, operation, enforcement and control of the proper use of such structures and the measures implemented to discourage the use of private vehicles.
\end{abstract}

Keywords: Shared bus-bike lanes, guidelines, Paris.

\section{RESUMEN}

Compartir los carriles exclusivos de buses con ciclistas es una buena alternativa para fomentar el transporte público y el ciclismo dentro de ciudades consolidadas, ya que permite proveer una infraestructura para ciclismo en lugares en donde por el limitado ancho de vía no es posible proveer una infraestructura independiente. Combinar dos modos de transporte en el mismo espacio genera otras preocupaciones, por lo que el diseño de un carril compartido además de asegurar eficiencia debe precautelar la integridad de los ciclistas. La falta de un estándar para el diseño de carriles compartidos para buses y bicicletas ha limitado la implementación de éstos en ciudades de países en desarrollo que generalmente carecen de recursos económicos y técnicos para emprender investigación. El análisis de algunas normativas utilizadas en Europa, Norte América y Australia para el diseño de carriles compartidos entre buses y ciclistas coinciden en que el tipo de infraestructura para bicicletas y su alineación dentro del carril compartido, así como el ancho del carril, son los parámetros que principalmente deben considerarse para garantizar la seguridad y la eficiencia de estos dos modos. La revisión del sistema de movilidad en buses y bicicletas en París muestra que el incremento del uso de transporte público y de la bicicleta depende no sólo de la calidad de la infraestructura construida, sino sobre todo de la coordinación entre el diseño, operación y control del uso adecuado de dichas estructuras y de las medidas implementadas para desfavorecer el uso del vehículo privado.

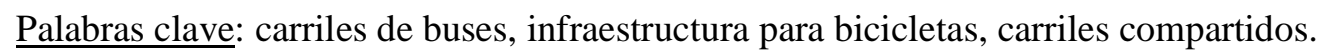




\section{INTRODUCTION}

According to the World Population Data Sheet is in 2016 the population growth rate $1.2 \%$ and $54.5 \%$ of the population lives in urban settlements (Population Reference Bureau, 2016). In consequence of the population growth and the rising migration from the rural to the urban area, urbanization expanded, traffic flow increased, and mobility reduced. In the context of this study, mobility refers to the capacity of citizens to freely move from one place to another by any mode of transportation, using the infrastructure of the urban system. It relates to transportation, both public and private.

The outcome of the uncoordinated growth of cities and the massive increase of private cars, as symbol of freedom or power, led to an uncontrollable expansion of the motorization rate; corresponding worldwide in the period 2005-2014 to an increase of 25\%. The increment is highest in Asia, Oceania and the Middle East with respectively 123\%, followed by Central and South America with 59\% (ACEA, 2016). It is estimated that the required infrastructure for transport absorbs up to one-third of the entire city surface. Similar, the transportation sector represents up to one-third or even more of the entire energy demand of a country. Moreover, due to the fossil fuels dependence of the transportation, the oil consumption in this sector increased by $120 \%$ in the period 1973-2010. In addition, $\mathrm{CO}_{2}$ emissions from the transport sector remain constant around 23\% despite the development of greener technologies (United Nations, 2013). Apart of greenhouse gas, is the transport sector responsible for other pollutants that cause an array of environmental problems, such as air pollution, extreme temperatures, flooding, etc. The excessive motorization causes health problems (road traffic accidents, diseases related to air and noise pollution, reduced physical activity, mental health, traffic stress; etc.), and social problems (community severance, isolation, and urban sprawl). Also, there are more pedestrian/vehicle conflicts causing safety concerns and traffic delays, visual intrusion caused by elevated roads and other infrastructure resulting in a distortion of the city image, finally disturbing the livability (Gehl, 2011) and the tourism potential (Reza, Miandoabchi, Szeto \& Rashidi, 2013; United Nations, 2013).

Different programs aiming to reach an environmentally sustainable urban mobility system have been promoted, such as car-sharing which allows people to enjoy the car benefits without the responsibilities of its ownership. The metro-bike sharing, the bus-bike sharing, and bike sharing enables people to use or borrow a bike from one point to another point in the city. However, all those schemes impose demands on the urban design which represents a constraint in consolidated cities with limited right-of-way, hindering strongly the provision of independent cycling infrastructures. A solution, gaining more and more interest is combining traffic modes in the same space.

For example, Shared Bus-Bike Lanes (SBBLs) are bus lanes in which cycling is allowed. They let the cycling network to continue when space is lacking for separate facilities and provide a more direct route taking advantage of the current segregated bus network in which the speed and flow are lower than in the car traffic lanes. Although the design of independent cycling infrastructure recently gained huge attention, there is little research about the design of SBBLs and even fewer studies to support the guidelines of such designs. Worldwide there is not a general standard for the implementation of a SBBL, instead, some states or municipalities experimented with different designs and regulations to meet local conditions. Therefore, there is currently no evidence of one design being more effective than the other (Hillsman, Hendricks \& Fiebe, 2012; De Ceunynck, Dorleman, Daniels, Laureshyn, Brijs et al., 2016). Even the information proportioned in the guidelines is different and sometimes ambiguous.

Most developing cities, by lack of resources to undertake research, tend to assume the norms or guidelines applied in other cities. In consequence, the application of SBBLs has been limited despite its potential (Reid \& Guthrie, 2004; Pucher, Dill \& Handy, 2010; Hillsman et al., 2012; Hurwitz, Jannat, Warner, Monsere \& Razmpa, 2014; De Ceunynck et al., 2016). To improve the understanding and application of SBBLs, this paper gathered relevant guidelines for the design of SBBLs and highlights the design parameters that influence cycling ridership. The document is structured as follows: Section 2 introduces some precedents and concepts of bus lanes; Section 3 describes SBBLs including an overview of design recommendations; Section 4 presents a description of bus lanes and the cycling infrastructure in Paris, as reference model of public transportation and cycling ridership; and Section 5 summarizes some conclusions. 


\section{PRECEDENTS AND CONCEPTS OF BUS LANES}

A bus lane is a lane reserved for buses aiming to reduce the travel time by providing access to the lane only to buses. On those lanes buses are not disrupted by other traffic, especially private vehicles neither during off-peak nor peak hours. The first designated bus lane in the world was in Chicago in 1940. In Europe, bus lanes were operating 20 years later when the closed tram tracks were converted to bus lanes (Agrawal, Goldman \& Hannaford, 2012). Until the 50s, cities developed its road infrastructure based on the needs of motorized modes. In that period, cars were considered an icon of progressive thinking. Traffic grew rapidly and roads and parking places were built everywhere to alleviate congestion. In consequence, during the 60's many bus lanes in different North American cities were abandoned, since the number of passengers was not enough to cover the operational costs. Abandoned bus lanes were converted in parking lots or used as other general traffic lanes (Agrawal et al., 2012). Between 1967 and1973, cities in Europe realized that the further expansion of the road network was not the way to proceed, since roadway improvements attracted more vehicles, incrementing traffic jams, gridlocks and air pollution. Awareness about the preservation of the planet arose, demanding new strategies to create a more productive, sustainable and livable city for all citizens. The conception of urban planning changed, planners started to re-think the city based on the needs of its citizens, limiting the space for roads and expanding areas for recreation. The aim of reducing $\mathrm{CO}_{2}$ emissions from the transportation sector led some cities to redouble their efforts to discourage the use of private vehicles and to encourage over again public transport by making bus lanes operational again.

The design of bus lanes requires balancing many competing factors. In addition, to accommodate the safe and efficient operation of buses, bus lane design must account for the maintenance of traffic flow, the needs for curbside access, the safety of pedestrians and cyclists, and the activity patterns that can vary significantly on a block-by-block basis. Commonly bus lanes are adjacent to the right curbside and concurrent with the traffic flow. However, they can be adjacent to the left curbside or in the median lane, concurrent with the traffic flow or in contraflow, in which buses run in opposite direction to the traffic. The minimum recommended bus lane width is $3.40 \mathrm{~m}$ in the United States and it varies between 2.5-3.50 $\mathrm{m}$ in Europe (De Ceunynck et al., 2016). Considering that a standard bus is $2.55 \mathrm{~m}$ wide, 3.15 $\mathrm{m}$ included mirrors, and that an additional space of $0.25 \mathrm{~m}$ on each side is required (Agrawal et al., 2012), the bus lane width should be at least $3.60 \mathrm{~m}$ to decrease the risk of crashes (Sando \& Moses, 2010). Case studies on narrower operating bus lanes demonstrated that even these lanes can improve the traffic conditions of buses (Reid \& Guthrie, 2004; Agrawal et al., 2012; Hillsman et al., 2012).

\section{SHARED BUS-BIKE LANES}

A shared bus-bike lane (SBBL) is a bus lane in which bicyclists are allowed. England, Ireland, France, Germany and Denmark allow bike cycling in bus lanes since their introduction. However, little research has been done to support their guidelines and standards that could be used by other nations (Agrawal et al., 2012). In the United States, the first SBBL is in operation since the late 1980s (Coastal HighwayMaryland) and the majority of bus lanes was established after 2000.

Although it is expected that in SBBLs there will be more bus-bike conflicts, reports of case studies show that after the implementation of a SBBL bicycling in the area increased and bicycle crashes decreased (Reid \& Guthrie, 2004; Hillsman et al., 2012) because bicyclists become more prudent in the presence of buses (De Ceunynck et al., 2016). Moreover, it was demonstrated that allowing cycling on a bus lane positively influences the route choice of the cyclists (Reid \& Guthrie, 2004; Pucher et al., 2010; Hurwitz et al., 2014). Cyclists do realize that in general buses have lower speed than other motorized modes, increasing the perceived safety level. Additionally, the use of bus lanes results in general in a reduction of the travel time since cyclists can develop a higher speed and select more direct routes than what possible is in independent cycle lanes. Furthermore, cyclists and buses are not delayed if the SBBL is wide enough (Reid \& Guthrie, 2004; Hillsman et al., 2012; De Ceunynck et al., 2016). 


\subsection{Design recommendations}

In SBBLs two traffic modes of different mass and speed interact with each other, therefore safety deserves a great consideration in the design (Hillsman et al., 2012). The term interaction refers to any encounter between a bus and a cyclist. These interactions in general take place when a cyclist passes or overtakes a stopped or moving bus or when a bus overtakes a moving cyclist. Beyond the parameters considered in a normal bus lane, designing a SBBL should add parameters that diminish the probability of interaction between the bicycle and bus flow (Reid \& Guthrie, 2004; Baumann, Brennan \& Zeibots, 2012; Pucher \& Buehler, 2012; Frings, Parkin \& Ridley, 2014) such as, the cycling infrastructure, the position of the bicycle lane inside the SBBL, the width, the surface maintenance, the control and enforcement program.

Firstly, it is important to note that the cycling infrastructure inside the SBBL varies with the cycling and bus flow. Table 1 shows the recommended cycling infrastructure considering the hierarchy of the road and a bus flow less or equal than 20 buses/h or 100 buses+taxis/h (if the presence of taxis is allowed) (Aluvihare, 2014; Heydon \& Smith, 2014; Transport for London Consultation, 2014). If the cyclist flow is higher than 2000 cyclist/h, the cycling infrastructure should be independent with special considerations on physical constraints, the degree of separation, the design speed (30 km/h) and the cyclist flow characteristics (casual or commuter) (Pucher et al., 2010, Aluvihare, 2014; Transport for London Consultation, 2014). Secondly, it is advisable to provide the cycle lane in the left-side of the SBBL to reduce bus-bike interactions caused by bus stops to pick-up and drop-off passengers (Hillsman et al., 2012).

Table 1. Recommended cycling infrastructure according to the road hierarchy and assuming a bus flow less or equal to 20 buses/h or 100 buses+taxis/h (Sando \& Moses, 2010).

\begin{tabular}{lccl}
\hline \multicolumn{1}{c}{ Type of road } & $\begin{array}{c}\text { Capacity } \\
\text { PAE }^{1} / \text { lane/h }\end{array}$ & $\begin{array}{c}\text { Maximum speed } \\
(\mathrm{km} / \mathrm{h})\end{array}$ & \multicolumn{1}{c}{ Cycling infrastructure } \\
\hline Local & 1,000 & 30 & $\begin{array}{l}\text { Normal SBBL }(3.6 \mathrm{~m}) \\
\text { Wide SBBL with advisory cycle } \\
\text { Primary/secondary }\end{array}$ \\
$\begin{array}{ll}\text { Mayor roads } \\
\text { lanside }(>3.6 \mathrm{~m})\end{array}$
\end{tabular}

Regarding the width of the SBBL, as shown in Table 2, two trends can be distinguished. Some guidelines recommend that SBBLs should be wide enough to facilitate the safe overtaking of bicyclists by buses, or narrow enough to prevent the overtaking of the bicyclists within the bus lane borders, while several countries only suggest a minimum width to facilitate overtaking. In general, if the width is less than $3.60 \mathrm{~m}$, the SBBL is considered narrow, otherwise it is wide. Figure 1 shows the trajectory of passing bicyclists and the common conflict points in a narrow SBBL (Fig. 1a) and in a wide SBBL (Fig. 1b). As it is depicted in Fig. 1a, in a narrow SBBL the bicyclist should occupy the adjacent generalpurpose lane to the left to pass the bus.

Most guidelines agree that the SBBL must be at least $4 \mathrm{~m}$ wide (Nicholson, 1978; Reid \& Guthrie, 2004; Parkin, Wardman \& Page, 2007; Parkin \& Meyers, 2010; Cardiff Cycle Network, 2011)). This minimum width requirement was corroborated by analysis of crash results that revealed that in narrower SBBLs, with a width less than $3.60 \mathrm{~m}$, there is more probability of sideswipe and mirror crashes. Also, a rapid increase in conflicts related with close overtaking maneuvers (a bus overtakes a bicyclist with a lateral distance less than $1 \mathrm{~m}$ ) and close bicycle-following situations (a bus drives behind a bicyclist with a time gap less than $2 \mathrm{~s}$ ) was observed. However, the interactions produced a change in the cyclist's behavior, who ride faster than in normal traffic lanes (Reid \& Guthrie, 2004; Sando \& Moses, 2010, De Ceunynck et al., 2016). On the other hand, Shackel \& Parkin (2014) found that wider SBBLs (with a width larger than $4 \mathrm{~m}$ ) lead to larger overtaking distances but also to higher overtaking speeds, which might result in a higher instability of the bicyclist. Thus, if the width could be between 4.25 and $4.60 \mathrm{~m}$, an advisory cycle lane should be included within the bus lane to minimize interactions.

1 Passenger Auto Equivalent 


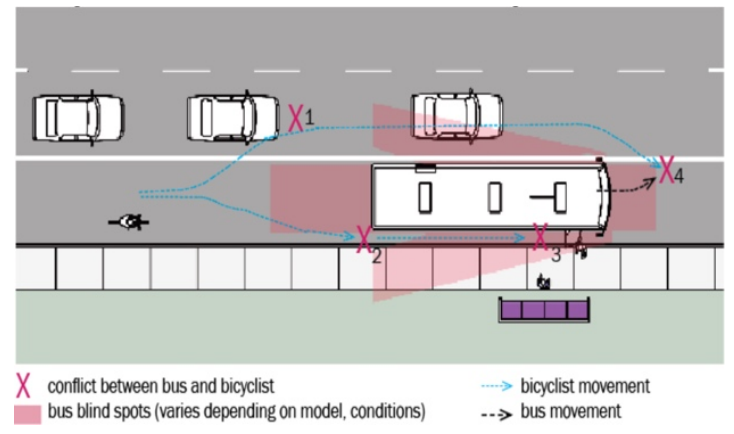

(a)

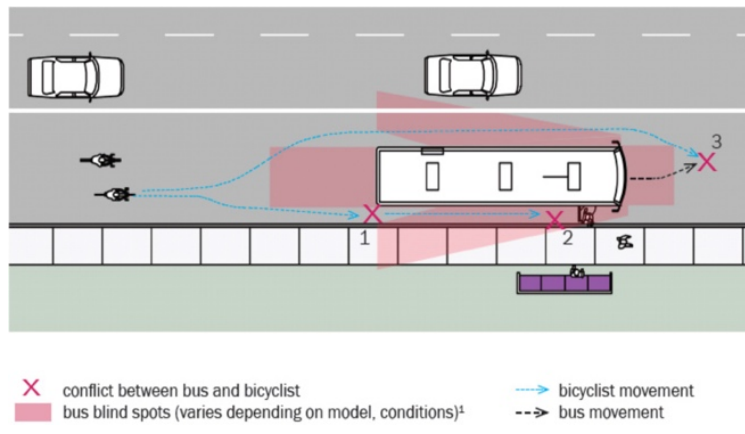

(b)

Figure 1. Conflict points on (a) narrow Shared Bus/Bike Lanes (SBBLs) and (b) wide SBBLs. Superimposed lines (blue) show the trajectory of the cyclist when he/she is overtaking the bus and crosses (red) depict common conflict points (Lin, Lee, Kourtellis \& Saxena, 2010).

Another aspect that will help to decrease the interaction between buses and bicyclists is the maintenance of the surface. Bus lanes are subject to more rapid surface deterioration and bicyclists are more vulnerable to imperfections in pavement surface. The safe interaction between both traffic modes requires the implementation of a more frequent inspection and a prioritized maintenance and repairing program. Finally, considering that the traffic conditions in SBBLs are better than in general-purpose lanes, non-authorized vehicles are tempted to use them to evade congestion in the general-purpose lane. To guarantee the proper operation of SBBL's, justifies a strong enforcement and control system able to anticipate dangerous situations. The latter should include a proper signaling to decrease the number of wrong-way bicyclists in SBBLs; guidelines for the movement of buses and bicyclists within the SBBL; patrol- and camera-based control to identify offenders; and training programs for bus operators in the presence of bicyclists.

\section{OVERVIEW OF THE MOBILITY SYSTEM IN PARIS}

Paris is the fifth largest city of the European Union with a population of 2,241,346 inhabitants in 2017. Paris began developing a network of curbside bus lanes in the 1960s. In the late 1990s and early 2000s, air quality concerns emerged as a key motivation for Paris' reinvention of its bus priority network (Agrawal et al., 2012). Mobilien, a regional road infrastructure project to improve the road network in favor of the public transportation was implemented in 2000; it is Paris' version of what we know as a bus transit system. Today, the bus lane system extends over $190 \mathrm{~km}$ with a minimum width of $3 \mathrm{~m} ; 41$ $\mathrm{km}$ of these lanes operate under the BRT system (Global BRT Data, 2017). Over the past decade, bus lanes have been widened and segregated from general traffic. Moreover, around $157 \mathrm{~km}$ of bus lanes are free to share with cyclists (Agrawal et al., 2012). The minimum width of SBBLs is $4.50 \mathrm{~m}$.

The cycling ridership within the city has increased from 1.66 to $2.73 \%$ in the period $2005-2015$ (L’Observatoire des Déplacement à Paris, 2015). The success of the cycling system was achieved through the largest bicycle sharing program in the world, Velib. This bike sharing program has in the city a cycling station every 300 meters. Studies report that $79 \%$ of the Velib trips are to access public transport stations (Pucher \& Buehler, 2008). In addition, a complete package to discourage the private car usage was implemented, which consists of calmed zones, car-free zones, narrowed roadways and widened sidewalks, total elimination of free parking, and education and recreation programs such as Paris Respire. 
Table 2. Reviewed guidelines and recommended width of operating SBBLs.

\begin{tabular}{|c|c|c|}
\hline Country/city & Guideline & Minimum lane width \\
\hline United States & $\begin{array}{l}\text { AASHTO (2012). Guide for the } \\
\text { development of bicycle facilities }\end{array}$ & $4.27 \mathrm{~m}$ \\
\hline Tucson $\mathrm{Az}^{2}$ & Pavement Marking Design Manual & $\begin{array}{l}3 \mathrm{~m} \text { minimum, } 3.6 \mathrm{~m} \text { standard, signaling is } \\
\text { optional }\end{array}$ \\
\hline $\begin{array}{l}\text { City of San } \\
\text { Francisco }^{3}\end{array}$ & Bicycle plan update & $3 \mathrm{~m}$ minimum, $4 \mathrm{~m}$ standard \\
\hline $\begin{array}{l}\text { Alburquerque }^{4} \\
\text { NM }\end{array}$ & $\begin{array}{l}\text { Albuquerque's bikeways and trails } \\
\text { master plan design guidelines }\end{array}$ & $3 \mathrm{~m}$ minimum, $4 \mathrm{~m}$ standard \\
\hline $\begin{array}{l}\text { City of } \\
\text { Minneapolis }{ }^{5} \mathrm{NM}\end{array}$ & $\begin{array}{l}\text { City of Minneapolis' bicycle facility } \\
\text { design guidelines }\end{array}$ & $3.60 \mathrm{~m}$ minimum, 4.6-5.5 m recommended \\
\hline Washington state & $\begin{array}{l}\text { Washington State Department of } \\
\text { Transport (WSDOT) }\end{array}$ & Where bus speeds and volumes are low ${ }^{6}$. \\
\hline Illinois ${ }^{7}$ & Illinois Department of Transport & $\begin{array}{l}\text { Outside lane with a minimum width of } 5 \mathrm{~m} \text { to } \\
\text { the curb face. }\end{array}$ \\
\hline Otawa/Canadá ${ }^{8}$ & $\begin{array}{l}\text { Design treatments for bicycles and } \\
\text { buses on arterials and collector roads }\end{array}$ & $\begin{array}{l}4-4.5 \mathrm{~m} \text { where the bus Flow is less or equal } \\
\text { to } 20 \text { buses/h, cyclist volume is less or equal } \\
\text { to } 50 \text { cyclists/h and the bus operating speed is } \\
\text { less or equal to } 60 \mathrm{~km} / \mathrm{h} \text {. }\end{array}$ \\
\hline Victoria/Australia ${ }^{9}$ & Vic Roads Cycle Notes No. $19^{10}$ & $\begin{array}{l}\text { Between } 4.2 \text { and } 4.5 \mathrm{~m} \text { where motor vehicle } \\
\text { traffic speeds are up to } 60 \mathrm{~km} / \mathrm{h} \text { and } 4.5 \text { to } 5.0 \\
\mathrm{~m} \text { where motor vehicle traffic speeds are up } \\
\text { to } 80 \mathrm{~km} / \mathrm{h} \text {. }\end{array}$ \\
\hline United Kingdom & Cardiff cycle design guide, 2011 & $4.6 \mathrm{~m}$ \\
\hline $\begin{array}{l}\text { England, Wales } \\
\text { and Scotland }\end{array}$ & Cycle infrastructure design & $4 \mathrm{~m}$ minimum, $4.24 \mathrm{~m}$ recommended \\
\hline Dublin/Ireland & Cycle track design guidelines manual ${ }^{11}$ & $3.5 \mathrm{~m}$ minimum, $4 \mathrm{~m}$ recommended \\
\hline British Columbia & $\begin{array}{l}\text { Capital, regional and district pedestrian } \\
\text { and cycling master plan design } \\
\text { guidelines }\end{array}$ & $4.5-5 \mathrm{~m}$ \\
\hline France & $\begin{array}{l}\text { Groupe de Recherche et d'Action des } \\
\text { Cyclistes Quotidiens (GRACQ }\end{array}$ & $3.5-4.5 \mathrm{~m}$ \\
\hline Belgium & Vademecum bicycle infrastructure $^{12}$ & $\begin{array}{l}\text { SBBLs are allowed only in lanes less than } 3.5 \\
\text { m and preferably only for short distances }\end{array}$ \\
\hline Germany & Straßenverkehrssicherheitsrichtlinie & $\begin{array}{l}4 \mathrm{~m} \text { for bus speeds } 40 \mathrm{~km} / \mathrm{h} \text { or less, } 4.25 \mathrm{~m} \\
\text { for bus speeds up to } 50 \mathrm{~km} / \mathrm{h} \text {. }\end{array}$ \\
\hline Austria & Cycling aspects of Austroads guides ${ }^{13}$ & $3.7-4.3 \mathrm{~m}$ \\
\hline Denmark & Vejdirektoratet, $2009^{14}$ & $4.5 \mathrm{~m}$ only for moderate bicyclist flow \\
\hline Sweden & $\begin{array}{l}\text { Vägar och gators utformning - sektion } \\
\text { tätort - gaturum }{ }^{15}\end{array}$ & 4.5-5.0 m depending of the bus speed \\
\hline
\end{tabular}

Pima County DOT, City of Tucson DOT

Alta Planning + Design and Parisi Associates, 2003

Alta Planning + Design and Gannett Fleming West, 2010

5 City of Minneapolis, 2010

6 No threshold values for high or low volumes or speeds

7 Illinois DOT, 2011

8 Dillon Consulting 2009

9 Ker, Moore \& Yapp, 2005, Australia

${ }^{10}$ Victoria Department of Transport

11 Dublin Transportation Office

12 Flemish Government, 2014

13 Veith \& Eady, 2014

14 Vejdirektoratet. Kollektiv bustrafik (2009) (in Danish)

15 Vägverket, Svenska Kommunförbundet (2004) 
The Paris bike lane network consists of $700 \mathrm{~km}$ including "piste cyclable" (bicycle paths) and "bande cyclable" (a cycle lane at the level of the road, separated from the other lanes by a longitudinal line or a specific marking) (Direction Territoriale Paris, 2009). A French survey revealed that $42 \%$ of cyclists were enthusiasts for shared bus-bike lanes, versus 33\% who had mixed opinions, and $27 \%$ who opposed them (Vélocité, 2005). Many cycling activists consider SBBLs more attractive than cycle paths, while others object them due to the closeness to the bus exhausts, a problem easily avoidable by replacing combustion buses with hybrid electric and/or electric buses.

If the cycling lane is unidirectional the width should approximately be $2 \mathrm{~m}$, but if bidirectional the width should be at least $3 \mathrm{~m}$. In the case of cycle paths, the width is $1.50 \mathrm{~m}$ for unidirectional and $3 \mathrm{~m}$ for bidirectional with a separation of $0.50 \mathrm{~m}$ between the footway and the cycling path and $0.50 \mathrm{~m}$ between the cycling path and the road (Pucher \& Buehler, 2012). Furthermore, Paris provides some international cycling routes such as EuroVelo 3 between Santiago de Compostela in Spain and Trondheim in Norway, and Avenue Verte between Paris and London. Figure 2 shows some shared bus/bike lanes in Paris.

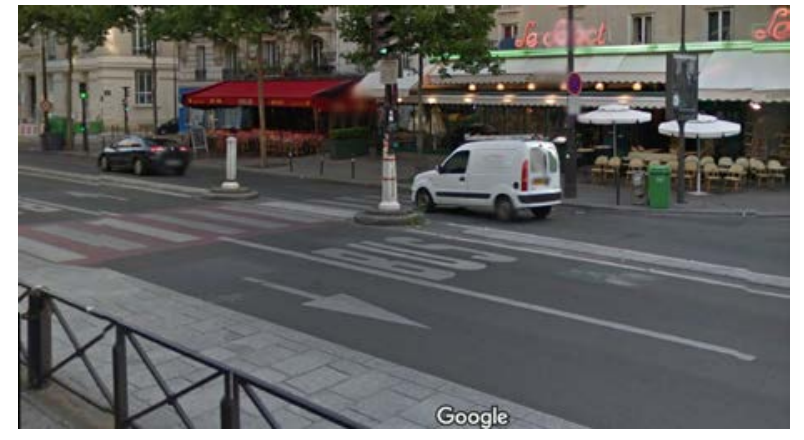

(a)

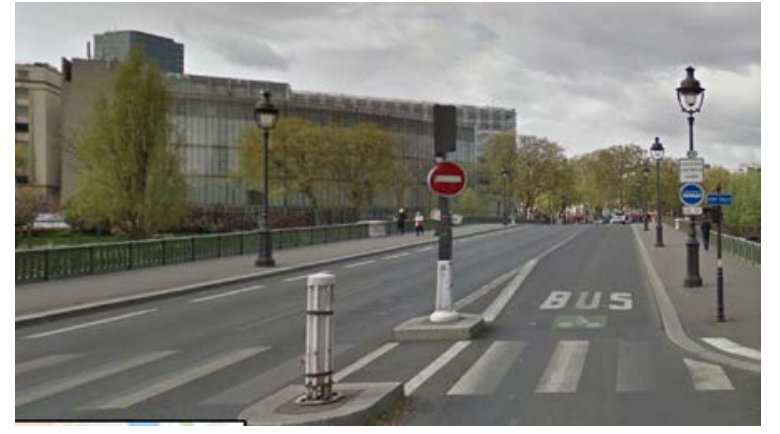

(b)

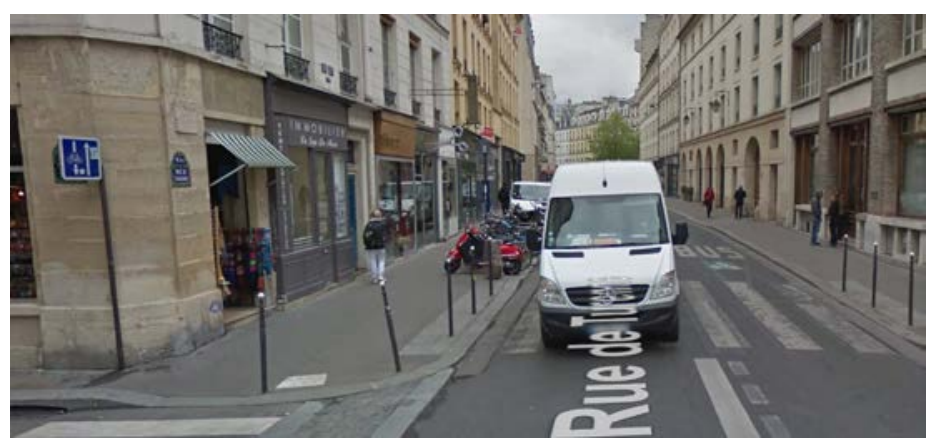

(c)

Figure 2. Shared bus-bike lanes in Paris on (a) the Boulevard du Montparnasse (June 2015), (b) the Pont de Sully (April 2016), and (c) on the Rue de Turenne (April 2016) (Google maps, 2016).

According to the law, bikes must be equipped with a bell and reflective elements on the pedals, lights in the front (white or yellow) and in the rear (red) (Direction Territoriale Paris, 2009). Moreover, cyclists can ride concurrent or in contraflow. Figure 3 shows some traffic signs related to SBBLs and cycling facilities.

The National Ministry of Education and insurance companies cooperate to provide extensive bicycling training courses in many schools, with bicycle safety permits issued in the 5th grade. Moreover, bicycling training courses for adults and seniors are offered twice a month (alternating arrondissements throughout Paris). Additionally, the "maison du velo" provides rental, repair and other services to cyclists, raising the cyclist comfort in the city. Furthermore, in theory every train should have inside an area available for bikes. 


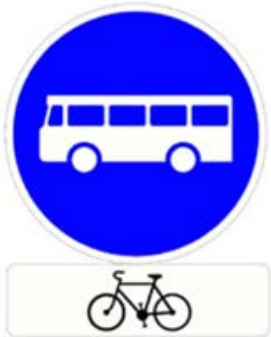

(a)

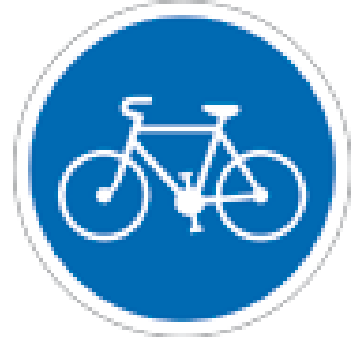

(b)

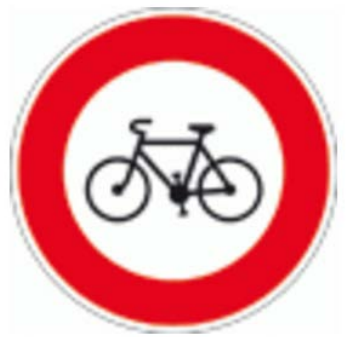

(c)

Figure 3. Traffic signal boards for a) shared bus-bike lanes, b) compulsory cycle lanes, c) no-access for bicycle (Paris signalization, 2011).

\section{CONCLUSIONS}

The growth of the population and the migration to cities generated a high rise in mobility demands. In a search for more sustainable solutions, authorities and governments decided to promote public transport. However, the excessive growth of motorization, especially of private vehicles, results every day in more traffic congestion, hindering the operation of buses that must compete for the right-of-way. To mitigate this situation, different cities around the world established exclusive bus lanes to prioritize public transport service over private modes. However, the lack of control in the operation of these lanes allowed unauthorized vehicles to use them either for parking, pick-up or delivery of products, etc., generating congestion inside them. As from 1970, awareness about the negative consequences of congestion arose; people started to realize that motorized transportation systems were causing serious problems in the environment, in the health of citizens and in the configuration of cities. Since then bus lanes-enforcement has been strengthened. Patrol-based control and video-based control were implemented, horizontal and vertical signaling was improved and strong systems of fines for violators were imposed. In the years 1990-2000, awareness in the preservation of the environment called the authorities and planners to reinforce not only their public transport systems, but also to encourage nonmotorized transport modes and discourage the use of private vehicles. Limited right-of-way in consolidated cities forced to think in more effective ways to provide cycling infrastructure and/or by allowing cyclists in exclusive bus lanes.

SBBLs are an effective way to promote cycling in consolidated cities with limited right-of-way, do not require additional infrastructure, and boost public transport and cycling by providing priority over other modes. Although worldwide there is not a standard for the design of SBBL, guidelines and case studies in Europe, North America and Australia agree that the design should diminish the probability of interaction between buses and cyclists. This bus-bike interaction probability is related to local conditions, but in general a design that considers the cycling infrastructure inside the SBBL (designated lane, segregated lane, adjacent lane), the position of the cycling infrastructure along the bus lane (left or right side) and the width (wide to facilitate a safe overtaking, or narrow to avoid the overtaking), guarantees safety and efficiency of bicyclists and buses, although the different mass and speed of both modes.

There is no clear recommendation of when to admit the presence of cyclists in exclusive bus lanes and when not. What is clear, however, is that the speed and intensity of each of the flows should be considered in the decision. If the volume of buses and cyclists is very high, it is preferable to provide separate infrastructures. Likewise happens if the speed of buses is very high, since the probability of fatal victims by buses-bicyclists interactions increases with the speed. Experienced cyclists find that sharing the lane with buses allows them to develop greater speed and take more direct routes, do not feel intimidated by buses and are safe when performing their maneuvers. They find that a wide bus lane allows them to maneuver safely without causing delays to buses and without being exposed to dangerous situations. To encourage less experienced cyclists to use SBBLs, signaling ought to be improved, and cyclists should be trained. Further, to make the infrastructure safer a strict maintenance program should be in place and bus operators trained in the presence of bicycles. 
The success of SBBLs depends on the coordination between design, enforcement and control operation as well as on the additional measures implemented to discourage the use of private vehicles. Paris possesses strong traffic and transport programs, in which the implementation of measures succeeded to increment the public transport and cycling ridership. Paris, like many European cities allows cyclists free access to all bus lanes, $42 \%$ of cyclists are enthusiastic about sharing space with buses. The priority of the Paris authorities has been to calm the traffic throughout the city limiting traffic speeds, reducing the right-of-way for private vehicles and by prioritizing public transport and nonmotorized modes. The success of the public transport system and the increment in cycling ridership in Paris are both thanks to the implemented measures to discourage the use of private vehicles, a strong enforcement for the operation of the bus lanes, extensive public bicycle programs, and a lot of intermodal aspects.

\section{ACKNOWLEDGEMENTS}

The author like to thanks SENESCYT for the financial support, without which this study would not have been possible.

\section{REFERENCES}

AASHTO. (2012). Guide for the development of bicycle facilities ( $4^{\text {th }}$ ed., $\left.17 \mathrm{pp}\right)$. Washington DC, NJ: American Association of State Highway and Transportation Officials.

ACEA. (2016). The automobile industry pocket guide 2016-2017. European automobile manufacturers association. Retrieved from http://www.acea.be/uploads/publications/ ACEA_Pocket_Guide_2016_2017.pdf

Agrawal, A. W., Goldman, T., Hannaford, N. (2012). Shared-use bus priority lanes on city streets: Case studies in design and management (No. CA-MTI-12-2606). Retrieved from http://transweb.sjsu.edu/PDFs/research/2606-shared-use-bus-priority-lanes-city-streets.pdf

Aluvihare, R. (2014). Designing networks and parking: A major task for the urban designer. Amsterdam, The Netherlands: Plan Amsterdam, 16-23. Retrieved from https://www.amsterdam.nl/publish/pages/847438/planam-04-2014_corr.pdf

Baumann, C., Brennan, T., Zeibots, M. E. (2012). Bike rider and bus driver interaction study - Draft report prepared for the City of Sydney. Sydney, Australia: Institute for Sustainable Futures, University of Technology Sydney, 23 pp. Retrieved from https://www.uts.edu.au/sites/ default/files/Baumannetal2012bikeandbus.pdf

Cardiff Cycle Network. (2011). Cardiff cycle design guide. Cardiff, U.K.: Cardiff Council, 123 pp. Retrieved from http://www.keepingcardiffmoving.co.uk/uploads/documents/37/ original/Design_Guide_FINAL.pdf?1319638020.

De Ceunynck, T., Dorleman, B., Daniels, S., Laureshyn, A., Brijs, T., Hermans, E., \& Wets, G. (2017). Sharing is (s)caring? Interactions between buses and bicyclists on bus lanes shared with bicyclists. Transportation Research Part F: Traffic Psychology and Behaviour, 46(B), 301-315, https://doi-org.kuleuven.ezproxy.kuleuven.be/10.1016/j.trf.2016.09.028.

Direction Territoriale Paris. (2009). Mobilité durable. Les pistes cyclables. N 7, aout 2009.

Flemish Government. (2014). Vademecum bicycle infrastructure. Brussels, Belgium.

Frings, D., Parkin, J., Ridley, A. (2014). The effects of cycle lanes, vehicle to kerb distance and vehicle type on cyclists' attention allocation during junction negotiation. Accident Analysis \& Prevention, 72, 411-421. doi: 10.1016/j.aap.2014.07.034

Gehl, J. (2011). Life between buildings: using public space. London, U.K.: Island Press.

Global BRT Data. (2017). Accessed May 19 ${ }^{\text {th }}$, 2017. Retrieved from http://www.brtdata.org. 
Google maps. (2016). Street view. Accessed May 18 ${ }^{\text {th }}, 2017$

Heydon, R., Smith, M. L. (2014). Making space for cycling: A guide for new developments and street renewals. Cambridge Cycling Campaign, Cyclenation, 36 pp. Retrieved from http://www.makingspaceforcycling.org/ MakingSpaceForCycling.pdf

Hillsman, E., Hendricks, S., Fiebe, J. (2012). A summary of design, policies and operational characteristics for shared bicycle/bus lanes. Tampa, FL: University of South Florida, 167 pp. Retrieved from https://www.nctr.usf.edu/wp-content/uploads/2012/11/77937.pdf

Hurwitz, D., Jannat, M., Warner, J., Monsere, C. M., Razmpa, A. (2014). Towards effective design treatments for right-turns at intersections with bicycle traffic. Portland State University, FHWAOR-RD-16-06 report, 284 pp. Retrieved from http://pdxscholar.library.pdx.edu/cgi/ viewcontent.cgi?article $=1317 \&$ context $=$ cengin_fac

L’Observatoire des Déplacement à Paris. (2015). Le Bilan des Déplacements en 2015 à Paris. Mairie de Paris, 2015. Retrieved from http://www.paris.fr/services-et-infos-pratiques/deplacements-etstationnement/deplacements

Lin, P., Lee, C., Kourtellis, A., Saxena, M. (2010). Evaluation of camera-based systems to reduce transit bus side collisions. Tampa, FL: University of South Florida, Center for Urban Transportation Research. Final Report: BDK85 Two 977-08, 90 pp. Retrieved from http://www.nctr.usf.edu/pdf/77905.pdf

Nicholson, F. (1978). Attitudes of a sample of cyclists to using single-track roads. Crowthorne, Berkshire: Access and Mobility Division, Transport Operations Department, Transport and Road Research Laboratory. No. TRRL Supp Report 357, Monograph

Parkin, J., Wardman, M., Page, M. (2007). Models of perceived cycling risk and route acceptability. Accident Analysis \& Prevention, 39(2), 364-371.

Parkin, J., Meyers, C. (2010). The effect of cycle lanes on the proximity between motor traffic and cycle traffic. Accident Analysis \& Prevention, 42(1), 159-165.

Population Reference Bureau. (2016). 2016 World population data sheet with a special focus on human needs and sustainable resources. Retrieved from http://www.prb.org/pdf16/prbwpds2016-web-2016.pdf

Pucher, J., Buehler, R. (2008). Making cycling irresistible: lessons from the Netherlands, Denmark and Germany. Transport Reviews, 28(4), 495-528.

Pucher, J., Dill, J., Handy, S. (2010). Infrastructure, programs, and policies to increase bicycling: an international review. Preventive Medicine, 50, S106-S125.

Pucher, J., Buehler, R. (2012). City cycling. Cambridge, MA: MIT Press, 416 pp.

Reid, S., Guthrie, N. (2004). Cycling in bus lanes. Berkshire, U.K.: Prepared for Charging and Local Transport Division, Department for Transport. TRL report 610, 32 pp.

Reza, Z., Miandoabchi, E., Szeto, W. Y., Rashidi, H. (2013). A review of urban transportation network design problems. European Journal of Operational Research, 229(2), 281-302.

Sando, T., Moses, R. (2010). Integrating transit into traditional neighborhood design policies - The influence of lane width on bus safety. Jacksonville, FL: University of North Florida, and FAMUFSU College of Engineering. Accessed March 2 ${ }^{\text {nd }}, 2012$ from http://www.dot.state.fl.us/ transit/Pages/LaneWidthonBusSafety.pdf

Shackel, S. C., Parkin, J. (2014). Influence of road markings, lane widths and driver behaviour on proximity and speed of vehicles overtaking cyclists. Accident Analysis \& Prevention, 73, 100-108 https://doi-org.kuleuven.ezproxy.kuleuven.be/10.1016/j.aap.2014.08.015

Transport for London Consultation. (2014). London cycling design standards consultation: Cycles lanes and tracks (Chap. 3), 69 pp. Retrieved from https://consultations.tfl.gov.uk/cycling/draftlondon-cycling-design-standards/user_uploads/ch3-cycle-lanes-and-tracks.pdf

United Nations. (2013). Planning and design for sustainable urban mobility. Global report on human settlements 2013. Abingdon-on-Thames, U.K.: Routledge, 348 pp. Retrieved from https://unhabitat.org/planning-and-design-for-sustainable-urban-mobility-global-report-onhuman-settlements-2013/ 
Veith, G., Eady, P. (2014). Cycling aspects of austroads guides. (2 ${ }^{\text {nd }}$ ed.). Sydney, Australia: Austroads Ltd.

Vélocité. (2005). La complémentarité entre vélo et transport public. La Revue du Cycliste Urbain, 79, Retrieved from http://www.fub.fr/velocite 